\title{
Application of Design of Experiment Based Innovative Approach in Method Development and Validation of RP-HPLC for Estimation of Azilsartan in Bulk and Pharmaceutical Tablet Dosage Form
}

\author{
Siddhata Arjun Deshmukh ${ }^{1, *}$, Suvarna Sharad Vanjari ${ }^{2}$, Rajendra Bhagwan Patil ${ }^{2}$, Kishanchandra \\ Radheshyam Khandelwal ${ }^{2}$
}

1Department of Pharmaceutical Quality Assurance, J.S.P. M.'s Rajarshi Shahu College of Pharmacy and Research, Survey No.80, Tathawade, Pune, Maharashtra, INDIA.

${ }^{2}$ Department of Pharmaceutical Chemistry, J.S.P.M.'s Rajarshi Shahu College of Pharmacy and Research, Survey No.80, Tathawade, Pune, Maharashtra, INDIA.

\begin{abstract}
Aim: Azilsartan is an angiotensin II receptor blocker used in the treatment of hypertension. Using the DoE based approach in reversed-phase high-performance chromatography method was developed and validated as per $\mathrm{ICH}$ guidelines. Materials and Methods: The

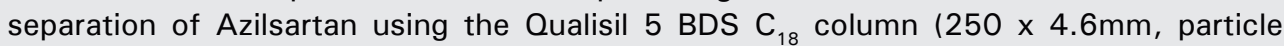
size $5 \mu$ ) in low-pressure gradient mode with photodiode array detector at $249 \mathrm{~nm}$. For optimization of chromatographic conditions for Azilsartan from its formulation with less number of experimental trials using Box-Behnken design. The critical quality attributes that are acetonitrile concentration in the mobile phase, $\mathrm{pH}$ of the aqueous phase and flow rate parameters were used to construct a mathematical model and study the effects of these independent factors on response such as retention time, tailing factor and theoretical plates. Analysis of Variance (ANOVA) confirmed that the three factors were significant its $\mathrm{p}$-value found less than 0.05. Results: Optimized experimental conditions obtained by the DoE approach for proposed work consists of water and acetonitrile $(75: 25 \% \mathrm{v} / \mathrm{v}), \mathrm{pH} 5.0$ adjusted with orthophosphoric acid as a mobile phase at a flow rate $1 \mathrm{ml} / \mathrm{min}$ with a retention time was found to be $3.516 \mathrm{~min}$. The developed method was validated as per ICH guidelines. An accuracy study was performed at three different levels and was found in the range of $98.94-100.46 \%$. Conclusion: The method was found simple and rapid with good specificity and robustness.
\end{abstract}

Key words: Azilsartan, ANOVA, Box-Behnken design, DoE approach, Robustness, Validation.

\section{INTRODUCTION}

Azilsartan is a selective AT1 subtype angiotensin II receptor antagonist and peptide hormone used as an antihypertensive drug. The mechanism of action is to lower blood pressure by inhibition of vasopressor hormone Angiotensin II that causes vasoconstriction. It increases blood pressure and aldosterone release. ${ }^{1-3}$ Apart from the role of the RAS in cardiac and renal treatment, it has been shown to meet the trademarks of the cancer. ${ }^{4}$ In recent studies it plays an important role in different cancer cells and tissues such as liver, lung, breast and pancreas. ${ }^{5}$ During absorption in the gastrointestinal tract, Azilsartan medoxomil is hydrolyzed to Azilsartan i.e. the active metabolite. After oral administration it is not detected in plasma. The Azilsartan medoxomil dose values are $40 \mathrm{mg}$ and $80 \mathrm{mg}$ once in a day. The bioavailability of Azilsartan is approximately 60\% and reached within 1.5 to $3 \mathrm{hr}$. Azilsartan is not
Submission Date: 09-03-2020; Revision Date: 27-04-2020; Accepted Date: 13-08-2020

DOI: 10.5530/ijper.54.3s.165 Correspondence: Miss. Siddhata Arjun Deshmukh

Department of Pharmaceutical Quality Assurance, J.S.P.M.'s Rajarshi Shahu College of Pharmacy and Research,

Tathawade, Pune 411033, Maharashtra, INDIA.

Phone: +919623836154

E-mail: siddhatadeshmukh22@gmail.com

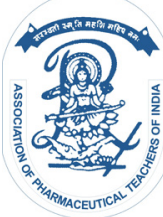

www.ijper.org 
dialyzable. The $80 \mathrm{mg}$ dose is recommended in adults taken by orally once daily. ${ }^{6,7}$

Chemically, Azilsartan is ((5-methyl-2-oxo1,3-dioxol-4yl) methyl 2-ethoxy1-((2'-(5-oxo4,5-dihydro-1,2,4-oxadiazol-3-yl)biphenyl4-yl) methyl)-1H-benzimidazole-7carboxylate). ${ }^{3}$ Azilsartan is crystalline powder in nature having off-white color and soluble in methanol and partially soluble in acetonitrile and insoluble in water. The literature review on the availability of analytical methods for Azilsartan revealed a UV spectroscopic method, ${ }^{7}$ few ultra-performance liquid chromatographic method and LC-MS methods for the quantification of Azilsartan in bulk drug, plasma $a^{8,9}$ and combination with other drugs ${ }^{10,11}$ and stability-indicating high-performance thin layer chromatographic (HPTLC) method. ${ }^{12}$ In the literature survey, many chromatographic analytical methods were developed having several drawbacks include high buffer concentration leads to column damage, time-consuming and tedious. It needs to develop a method that resolves the problems of the previous methods. ${ }^{13}$ In this experiment we are developing a new method by using the DoE approach. The chemical structure is presented in Figure 1.

The concept of quality by design was coined Joseph Juran a quality expert. According to him, quality could be planned to minimize the most quality crises and problems in the first place. QbD encompasses designing and developing formulations and manufacturing processes that ensure predefined product specifications. An understanding of how product and process variables influence product quality are required for QbD. In addition to this new concept being considered by FDA in its cGMP initiative, three important guidance documents were published as part of the International Conference on Harmonization (ICH) guidelines: Q8 (Pharmaceutical Development) and Q9 (Quality Risk Management). Q10 (Pharmaceutical

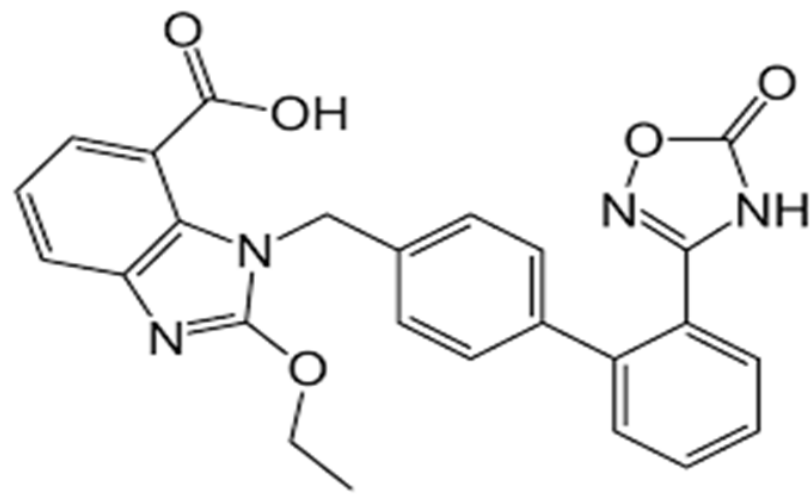

Figure 1: Structure of Azilsartan.
Quality System) also describes a model for an effective quality management system for the pharmaceutical industry. Recently in the literature, the application of $\mathrm{QbD}$ principles to pharmaceutical development and manufacturing has added a lot of interest. $\mathrm{QbD}$ is planned by pharmaceutical development, quality risk management and pharmaceutics quality system of ICH guidelines. ${ }^{14-17}$

The process of analytical method development using QbD included the first target product profile which defines the outlooks in the final step of method optimization called quality target product profile (QTPP) and also known as an analytical target profile (ATP). ${ }^{18}$ The second phase based on system suitability results gives performance criteria for the chromatographic method is developed. The third phase consists of a systematic process for the assessment, control, communication and review of risks to the quality of drug products across the product lifecycle. An assessment of risks. Risk assessment helps to increase the quality of the method or process. It is also a determining factor for the effect of the input variable on the method. From risk assessment can identify critical attributes that are going to affect final results. An Ishikawa or fishbone diagram is used to categorize all potential variables such as material, mobile phase, instrumental parameters, column characteristics and sample preparation. ${ }^{19}$ The fourth phase consists of setting chromatographic conditions and the availability of material known as method design. After method development, the software is used to generate data without actual experimentation. ${ }^{20}$ The fifth phase includes input material controls, process controls and, monitoring the design space around individual or multiple unit operations and/or final product specifications used to ensure consistent quality. The final phase consists of continuous improvement throughout the process to gain more knowledge and improve method quality. ${ }^{21}$

To estimate Azilsartan in pharmaceutical oral dosage form and biological samples, several analytical methods have been developed. The ICH (International Conference of Harmonization) Q1A(R2) guideline suggests that stress studies should be carried out on a drug to establish stability. ${ }^{22}$

In the present research, the design of experiment approach used to develop, optimized and validated according to ICH guidelines. Hence a new, precise, accurate and robust method was developed for Azilsartan in the pharmaceutical oral dosage form.

\begin{tabular}{|c|c|}
\hline $\begin{array}{l}\text { Chemical } \\
\text { dioxol-4vl) }\end{array}$ & $\begin{array}{l}\text { Name: } \\
\text { methyl }\end{array}$ \\
\hline
\end{tabular}


dihydro-1,2,4-oxadiazol-3-yl)

biphenyl4-yl)

methyl)-1H-benzimidazole-7-carboxylate)

Molecular Formula: $\mathrm{C}_{25} \mathrm{H}_{20} \mathrm{~N}_{4} \mathrm{O}_{5}$

Molecular Mass: $456.4 \mathrm{~g} / \mathrm{mol}$

Description: an off-white crystalline powder

Category: Antihypertensive

Dose: $40 \mathrm{mg}, 80 \mathrm{mg}$

Solubility: freely soluble in methanol, slightly soluble in acetonitrile, insoluble in water

Melting Point: $212-214^{\circ} \mathrm{C}$

\section{MATERIALS AND METHODS Instrumentation}

A quantitative HPLC system (Shimadzu Corporation, SPD-M20, Japan) equipped with LC solution software was used for LC studies, the detector was a photodiode array detector having a light source of deuterium (D2) and tungsten (W) lamp with a wavelength range of $190-800 \mathrm{~nm}$. It had an on-line degasser containing the binary pump and sample injector with a $20 \mu \mathrm{L}$ loop. Separation studies were carried out using $\mathrm{C}_{18}$ column Qualisil 5 BDS-C 18 (250mm $4 \mathrm{~mm}$ i.d., $5 \mu \mathrm{m}$ particle size) (Netherlands). $\mathrm{pH}$ meter (Labman scientific instrument Pvt. Ltd., Chennai, India) was used to adjust the $\mathrm{pH}$ of the mobile phase and other solutions used during the study. Other instruments also used during the study were, Analytical balance (Contech instrument Ltd., Pune, India), Sonicator (Citizen digital ultra sonicator) and suction pump (rocker 300A vacuum filtration system).

\section{Materials}

The working standards were a kind gift from Aurobindo pharma Pvt limited, Hyderabad, India. HPLC-grade acetonitrile and water were obtained from Merck Chemicals. The tablet Myotan ${ }^{\circledR}$ with label claim $40 \mathrm{mg}$ of Azilsartan from Synokem Pharmaceuticals LTD.

\section{Mobile Phase Composition}

In the current research doubled distilled water adjusted to $\mathrm{pH} 5$ by orthophosphoric acid and acetonitrile.

\section{Standard solution preparation}

The working standard of $10 \mathrm{mg}$ Azilsartan was taken in $10 \mathrm{ml}$ volumetric flask and acetonitrile was added followed by filling to the mark to obtain $1000 \mu \mathrm{g} / \mathrm{ml}$. Transfer $1 \mathrm{ml}$ from resulting solution to $10 \mathrm{ml}$ volumetric flask and volume was made up with acetonitrile to form $100 \mu \mathrm{g} / \mathrm{ml}$ stock standard solution. The $20 \mu \mathrm{g} / \mathrm{ml}$ was used for the optimization of the method.

\section{Sample solution preparation}

For assay preparation, 20 tablets (Myotan $^{\circledR} 40 \mathrm{mg}$ ) were ground and tablet powder equivalent to $100 \mathrm{mg}$ of Azilsartan was taken in a $100 \mathrm{ml}$ volumetric flask and diluted with acetonitrile. The solution was filtered through a $0.45 \mu$ filter. From the filtrate, an appropriate volume of solution was diluted to get a final concentration of $20 \mu \mathrm{g} / \mathrm{ml}$ using acetonitrile.

\section{Preliminary studies for method development}

The preliminary studies for method development were conducted using Shimadzu LC20AD high-performance liquid chromatography system (HPLC) with PDA using Lab solutions software. A Qualisil 5 BDS $C_{18}$ column $(250 \times 4.6 \mathrm{~mm}$, particle size $5 \mu)$ maintained at ambient temperature was used for the chromatographic separation. Before applying the DoE approach, the chromatographic condition was a low-pressure gradient developed using water ( $\mathrm{pH}$ adjusted to 5 using orthophosphoric acid) and acetonitrile $(80: 20 \mathrm{v} / \mathrm{v})$. The mobile phase was degassed and filtered through membrane filter $0.45 \mu$. The flow rate of $0.8 \mathrm{ml} / \mathrm{min}$ and an injection volume of $20 \mu \mathrm{L}$ was used. The run time for the analysis was 10 mins. Using a PDA detector, the detection was performed at $249 \mathrm{~nm}$.

\section{Analytical Target Profile (ATP) and Method Qualification}

Various components of ATP include characteristics like target drug, quality attributes for chromatographic method, sample preparation, instrument parameters and method application. Hence it begins with goal determination. This attention was given to the product and process understanding. The robust, accurate, precise and USP tailing less than 1.2 number of theoretical plates greater than 2000 and short analysis time i.e. less than $10 \mathrm{~min}$ was the method intended for the development of Azilsartan. ${ }^{23,24}$

Once the method was designed, the following step arises method qualification this was to confirm that method was carried out as intended. It was classified in design qualification, installation qualification, operational qualification and performance qualification.

\section{Risk assessment in method development}

A risk assessment of the drug substance attributes was performed to evaluate the impact that each attribute could have on the drug substance's CQAs. Factors were organized hierarchically using an Ishikawa or "fishbone" diagram also called as cause and effect diagram it was used as a primary tool in the process of risk analysis. It is 
simply defined as a diagram that shows the causes of an event. The fishbone diagram was used to assess critical effects caused by material, mobile phase, instrumental parameters, sample characteristics and preparation and column characteristics. ${ }^{25,26}$ Another tool for risk assessment conducted FMEA model was also used to found potential risk factors on the process and quality of the product. FMEA was identified by the risk priority number (RPN). The responsibility of risk was carried as severity (S), probability (P), detectability (D)..$^{27,28}$ It was shown in Figure 2.

\section{Statistical Software}

Design Expert (Version 12), Stat-Ease Inc. Minneapolis, MN, USA statistical computer software was operated for method optimization. The results of validation parameters were calculated by Microsoft Excel 2016 software.

\section{Preliminary screening of critical attributes factor}

The screening method for the design of experiment was used to identify the critical attribute factors (CQA). $\mathrm{C}_{8}$ and $\mathrm{C}_{18}$ column selection, the concentration of aqueous and organic mobile phase, $\mathrm{pH}$ adjustment of the mobile phase, detection of wavelength, the temperature of column, isocratic/gradient flow of mobile phase, flow rate and volume of injection were used for the risk assessment. The process method parameters were initially investigated viz. the number of theoretical plates, retention time and tailing factor. In this experiment, the critical quality attributes were $\mathrm{pH}$ of the mobile phase, flow rate and acetonitrile concentration to develop a chromatographic analytical method by using DoE.

\section{RESULTS AND DISCUSSION}

\section{Box-Behnken design used for method optimization}

Several methods of RP-HPLC for estimation of Azilsartan were developed containing water, potassium

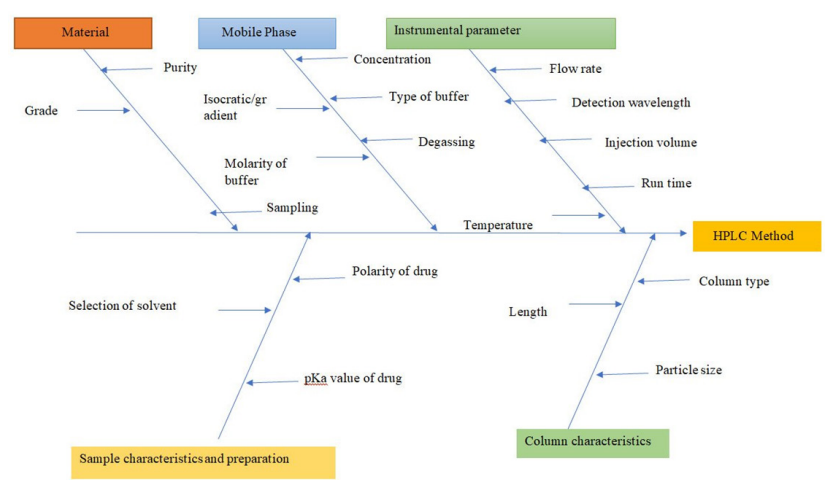

Figure 2: Fishbone diagram for HPLC method development. dihydrogen phosphate ammonium acetate, to attain good separation of the drug but they are not costeffective in case of solvent quantity used for regular analysis of Azilsartan in its bulk and pharmaceutical dosage form..$^{29,30}$ In the present study, the $3^{3}$ level and factor combinations of the Box-Behnken design type used with response surface methodology and the experiments were planned and conducted. The optimization was done by applying three levels of factors as reported in Table 1. Based on preliminary method development trials the levels were identified and used in statistical software to determine runs. The Box-Behnken design was selected for this study and it requires 13 runs for modeling a response surface. There were three independent factors, i.e. the $\mathrm{pH}$ of the mobile phase $\left(\mathrm{X}_{1}\right)$, flow rate $\left(\mathrm{X}_{2}\right)$, the concentration of solvent in the mobile phase $\left(\mathrm{X}_{3}\right)$ on the tailing factor $\left(\mathrm{Y}_{1}\right)$, retention time $\left(\mathrm{Y}_{2}\right)$, theoretical plates $\left(\mathrm{Y}_{3}\right)$.

The quadratic model and regression analysis applied for the USP tailing factor, retention time and theoretical plates of the peak. Regression analysis and p-values obtained from the software-generated reports were given in Table 2. To study the effect of the factors on the responses Analysis of variance (ANOVA) was performed. $p$-values provide the model is 'statistically significant' it is $p<0.05$. It was shown in Table 3 . The remaining confirmation of the method was completed using the concept of 'Desirability' by software analysis. Figure 6.

\section{Response Surface Methodology by DoE}

To recognize the interactions between the variables such as $\mathrm{pH}$ of the mobile phase, flow rate and acetonitrile concentration, the response surface diagrams (3D graphs and counter plots) were drawn for the whole experimental design.

\section{Quadratic Model Equations}

Tailing factor $\left(\mathrm{Y}_{1}\right)=+1.10-0.0700 \mathrm{~A}-0.0613 \mathrm{~B}-$ $0.2438 \mathrm{C}+0.0950 \mathrm{AB}+0.1100 \mathrm{AC}+0.0325 \mathrm{BC}$ $+0.0938 \mathrm{~A}^{2}+0.0663 \mathrm{~B}^{2}+0.0712 \mathrm{C}^{2}$ Retention time $\left(\mathrm{Y}_{2}\right)$
$=+4.47+0.0841 \mathrm{~A}-1.07 \mathrm{~B}+0.1813 \mathrm{C}+0.0360 \mathrm{AB}^{-}$
$1.1447 \mathrm{AC}-0.0607 \mathrm{BC}-0.1022 \mathrm{~A}^{2}+0.1973 \mathrm{~B}^{2}-0.1790 \mathrm{C}^{2}$

Table 1: Experimental plan of Box-Behnken design showing factors and levels.

\begin{tabular}{|c|c|c|c|c|}
\hline Code & Factors & Low & Medium & High \\
\hline $\mathrm{X}_{1}$ & $\mathrm{pH}$ & 4.5 & 5 & 5.5 \\
\hline $\mathrm{X}_{2}$ & Flow rate (ml/min) & 0.6 & 0.8 & 1 \\
\hline $\mathrm{X}_{3}$ & $\begin{array}{c}\mathrm{ACN} \\
\text { concentration (\%) }\end{array}$ & 15 & 20 & 25 \\
\hline
\end{tabular}




\begin{tabular}{|c|c|c|c|c|c|c|}
\hline \multicolumn{6}{|c|}{ Table 2: Design matrix of BBD constructed using critical factors with selected responses. } \\
\hline Sr. No. & $\mathbf{p H}$ & $\begin{array}{c}\text { Flow rate } \\
\text { (ml/min) }\end{array}$ & $\begin{array}{c}\text { ACN conc. } \\
\text { (\%) }\end{array}$ & $\begin{array}{c}\text { Tailing } \\
\text { Factor }\end{array}$ & $\begin{array}{c}\text { Retention } \\
\text { time (min) }\end{array}$ & $\begin{array}{c}\text { Theoretical } \\
\text { plates }\end{array}$ \\
\hline 1 & 4.5 & 0.8 & 15 & 1.65 & 3.598 & 4678 \\
\hline 2 & 5.5 & 0.8 & 15 & 1.33 & 4.162 & 4941 \\
\hline 3 & 5.5 & 0.6 & 20 & 1.13 & 5.743 & 3065 \\
\hline 4 & 4.5 & 0.8 & 25 & 0.98 & 4.505 & 5321 \\
\hline 5 & 5.5 & 1 & 20 & 1.21 & 3.449 & 4098 \\
\hline 6 & 5 & 1 & 25 & 0.94 & 3.516 & 5902 \\
\hline 7 & 5 & 0.6 & 15 & 1.6 & 5.339 & 4985 \\
\hline 8 & 5.5 & 0.8 & 25 & 1.1 & 4.49 & 4951 \\
\hline 9 & 5 & 0.6 & 25 & 1.01 & 5.568 & 3258 \\
\hline 10 & 4.5 & 1 & 20 & 1.2 & 3.315 & 3985 \\
\hline 11 & 5 & 0.8 & 20 & 1.1 & 4.47 & 5643 \\
\hline 12 & 4.5 & 0.6 & 20 & 1.5 & 5.753 & 3179 \\
\hline 13 & 5 & 1 & 15 & 1.4 & 3.53 & 4143 \\
\hline
\end{tabular}

\begin{tabular}{|c|c|c|c|c|c|c|c|}
\hline & Source & $\begin{array}{l}\text { Sum of } \\
\text { squares }\end{array}$ & Df & $\begin{array}{l}\text { Mean } \\
\text { square }\end{array}$ & F value & p-value & \\
\hline \multirow[t]{4}{*}{ Response Y1 (tailing factor) } & Quadratic model & 0.6569 & 9 & 0.073 & 34.62 & 0.007 & Significant \\
\hline & $\mathrm{X} 1$ & 0.0392 & 1 & 0.0392 & 18.59 & 0.0230 & \\
\hline & $\mathrm{X} 2$ & 0.0300 & 1 & 0.0300 & 14.24 & 0.0326 & \\
\hline & $\mathrm{X} 3$ & 0.4753 & 1 & 0.4753 & 225.44 & 0.0006 & \\
\hline \multirow[t]{4}{*}{ Response Y2 (retention time) } & Quadratic model & 9.97 & 9 & 1.11 & 13.43 & 0.0278 & Significant \\
\hline & $\mathrm{X} 1$ & 0.0566 & 1 & 0.0566 & 0.6864 & 0.4682 & \\
\hline & $\mathrm{X} 2$ & 9.23 & 1 & 9.23 & 111.90 & 0.0018 & \\
\hline & $\mathrm{X} 3$ & 0.2628 & 1 & 0.2628 & 3.19 & 0.1723 & \\
\hline \multirow[t]{4}{*}{ Response Y3 (theoretical plates) } & Quadratic model & $1.045 \mathrm{E}+07$ & 9 & $1.66 \mathrm{E}+06$ & 69.99 & 0.0025 & Significant \\
\hline & $\mathrm{X} 1$ & 1458.00 & 1 & 1458.00 & 0.0879 & 0.7862 & \\
\hline & $\mathrm{X} 2$ & $1.657 \mathrm{E}+06$ & 1 & 1.657E+06 & 99.86 & 0.0021 & \\
\hline & X3 & 58653.13 & 1 & 58653.13 & 3.53 & 0.1567 & \\
\hline
\end{tabular}

Theoretical

plates

$\left(\mathrm{Y}_{3}\right)$

$=+5643.00-13.50 \mathrm{~A}+455.12 \mathrm{~B}+85.63 \mathrm{C}+56.75 \mathrm{AB}-$ 158.25AC+871.50BC- 830.25 $\mathrm{A}^{2}-1231.00 \mathrm{~B}^{2}+160.00 \mathrm{C}^{2}$

The above quadratic model equations represent the effect of factors such as $\mathrm{pH}$ of the mobile phase, flow rate and acetonitrile concentration on responses tailing factor, retention time and theoretical plates. The "+" sign indicates a result that shows directly proportional whereas a "_" sign shows inverse relation. The representative plots for responses are presented in Figure $3 \mathrm{a}-\mathrm{c}$, in which the interactivity between variables factors $\mathrm{B}$ and $\mathrm{C}$ and their mutual dependence is clearly observed, while factor A is kept constant. Figure $4 \mathrm{a}-\mathrm{c}$ represents that acetonitrile concentration in the mobile phase showed an extrusive effect on retention time. The retention time is increased with a decrease in acetonitrile concentration in the mobile phase and increased or decreased in $\mathrm{pH}$ of aqueous mobile phase; there is show no result on retention time. The increased flow rate with decreased retention time. Figure 5 confirmed that the theoretical plates of the column increased with increased flow rate and acetonitrile concentration in the mobile phase while the $\mathrm{pH}$ of the aqueous phase showed an insignificant effect on theoretical plates. The tailing factor decreased with an increase in acetonitrile concentration in the mobile phase and increased flow rate, while the $\mathrm{pH}$ of the aqueous phase did not show any significant effect on the tailing factor.

During numerical optimization shown in Figure 5 a-c parameters for the desirability were considered as $\mathrm{pH}$, 


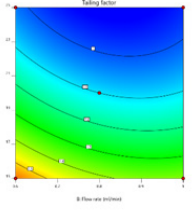

a)

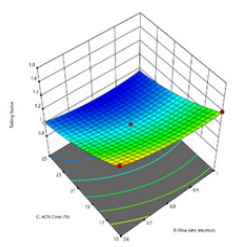

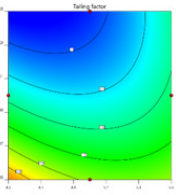

b)

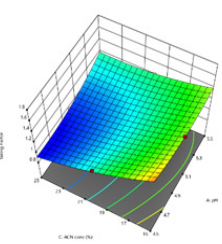

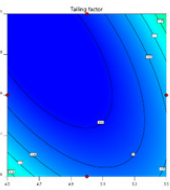

c)

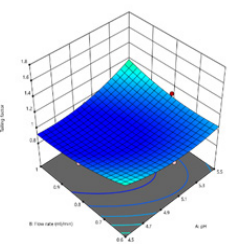

Figure $3(a-c)$ : Counter plots and 3-D response surface plots showing the influence of : a)pH, b)flow rate, c)\% $\mathrm{ACN}$ concentration on tailing factor.

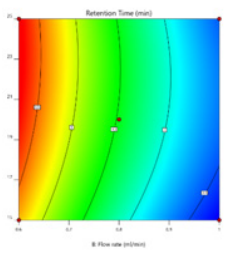

a)

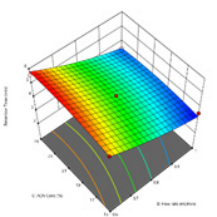

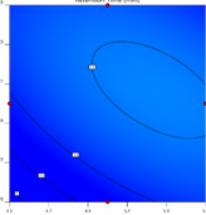

b)

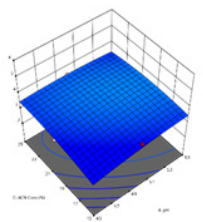

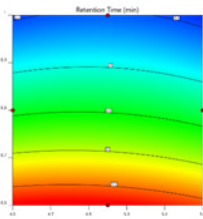

c)

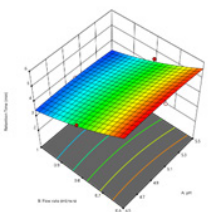

Figure 4 (a-c): counter plots and 3-D response surface plots showing the influence of : a)pH, b)flow rate, c)\% $\mathrm{ACN}$ concentration on retention time.

flow rate, acetonitrile concentration, tailing factor, retention time, theoretical plates and combined. Here the desirability of all parameters found to be $100 \%$. Hence the optimized chromatographic conditions, acetonitrile concentration $(25 \%)$, the flow rate for column $(1 \mathrm{ml} /$ $\mathrm{min}$ ) and $\mathrm{pH}$ of aqueous mobile phase (5). As a result the retention time was found to be $3.516 \mathrm{~min}$, tailing factor 0.94 and the number of theoretical plates were 5902, the chromatogram of Azilsartan was shown in Figure 7.

\section{Validation of method}

The chromatographic separation was validated for linearity, range, accuracy, precision, robustness, specificity, system suitability according to (Q2 R1) ICH guidelines. ${ }^{31}$
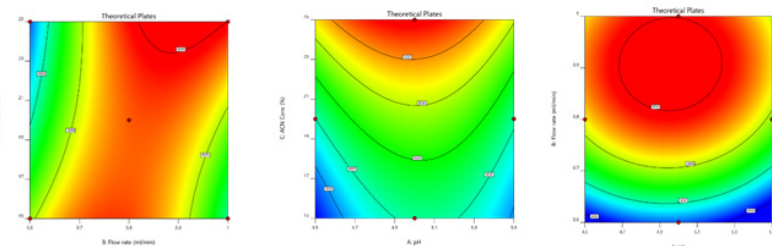

a)

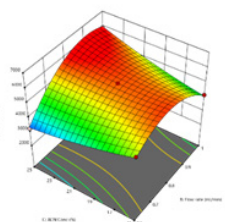

b)
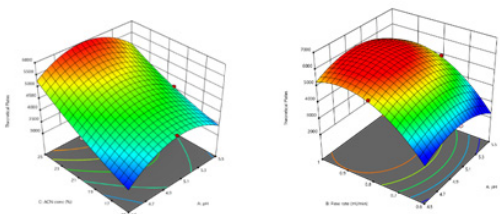

Figure 5 (a-c): Counter plots and 3-D response surface plots showing the influence of : a)pH, b)flow rate, c)\% $\mathrm{ACN}$ concentration on number of theoretical plates.

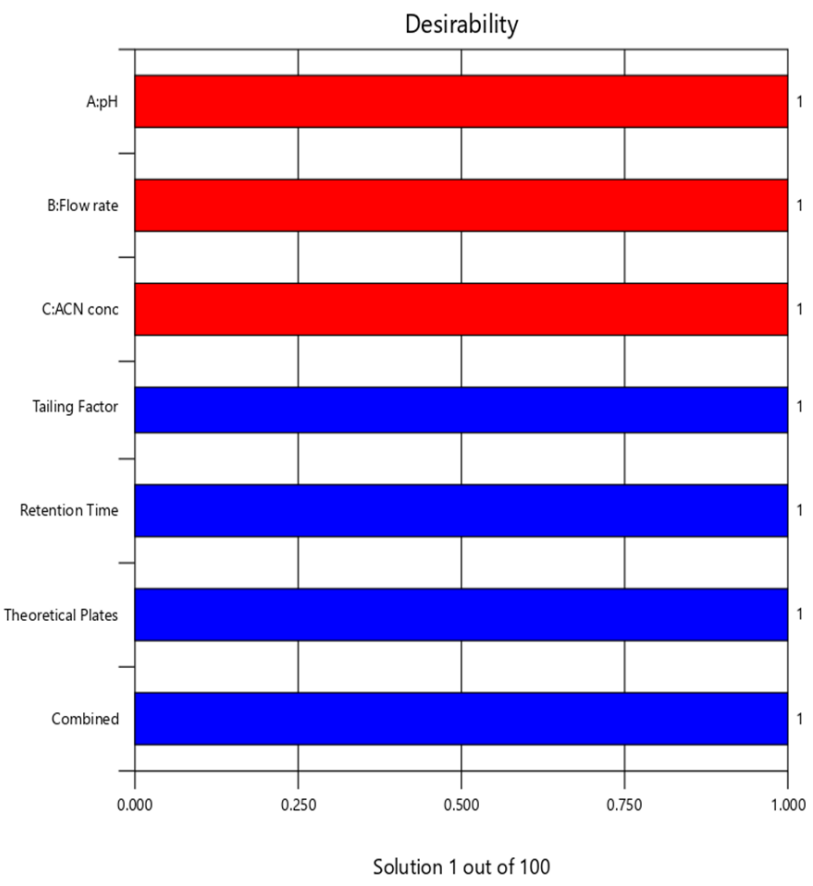

Figure 6: Desirability chart.

mAU

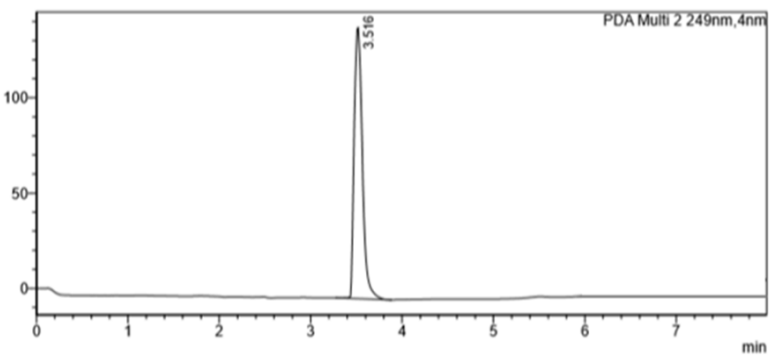

Figure 7: Chromatogram of Azilsartan $(100 \mu \mathrm{g} / \mathrm{ml})$. 


\begin{tabular}{|c|c|c|c|c|}
\hline \multicolumn{5}{|c|}{ Table 4: Developed and optimized experimental } \\
condition \\
Parameters & Specification & $\begin{array}{c}\text { Tailing } \\
\text { Factor }\end{array}$ & $\begin{array}{c}\text { Retention } \\
\text { Time (min) }\end{array}$ & $\begin{array}{c}\text { Theoretical } \\
\text { Plates }\end{array}$ \\
\hline pH & 5 & 0.94 & 3.516 & 5902 \\
\hline Flow rate & $1 \mathrm{ml} / \mathrm{min}$ & & & \\
\hline ACN & $25 \%$ & & \\
\hline
\end{tabular}

\section{System suitability}

For the system suitability study, the theoretical plates, peak area, tailing factor were studied. The acceptance criteria should meet the acceptance criteria. The six replicates of $20 \mu \mathrm{g} / \mathrm{ml}$ of Azilsartan were injected results were shown in Table 5.

\section{Linearity and range}

The five different serial concentrations were prepared for the standard calibration curve using acetonitrile in the rage of $5,10,15,20,25$ and $30 \mu \mathrm{g} / \mathrm{ml}$. The linearity was performed by three replicate injections of each concentration. The regression equation was $y=8898.3 x+755.33$ and the regression coefficient $R^{2}=0.9997$. It is shown in Figure 8 .

\section{Precision}

A repeatability study was studied within 6 replicate sets. The intraday study was performed by 3 replicates of 3 different i.e. 15,20 and $25 \mu \mathrm{g} / \mathrm{ml}$ of AZL was performed for intraday precision and interday precision (continuous 3 days) results were obtained. It was shown in Table 6, 7 .

\section{Accuracy}

Recovery study was performed by adding a known amount of drug corresponding to three concentrations, i.e. 50, 100 and $150 \%$ to the tablet formulation. It showed a satisfactory recovery of Azilsartan. The value of average $\%$ recovery and $\%$ RSD at each level was found within acceptance criteria that indicate the method is accurate. It was shown in Table 8.

\section{Robustness}

It is a measure of its robustness of an analytical procedure is a measure of its capability to remain unchanged by small, but intentional changes in method parameters and provides a signal that it was reliable in regular practice. There should be consistency of analysis with regarding for to planned variations in method parameters such as $\mathrm{pH}$ (4.5-5.5) and flow rate $(0.8-1.2 \mathrm{ml} / \mathrm{min})$ shown in Table 9 . The effect of each

\begin{tabular}{|c|c|}
\hline \multicolumn{2}{|c|}{ Table 5: System suitability } \\
\hline Parameter & Estimates \\
\hline USP Tailing & 0.94 \\
\hline Plate count & 5902 \\
\hline \%RSD of Peak areas & 0.59 \\
\hline Retention Time & 3.516 \\
\hline
\end{tabular}

\begin{tabular}{|c|c|c|c|c|}
\hline \multicolumn{5}{|c|}{ Table 6: Intraday Precision } \\
\hline Sr.No. & $\begin{array}{c}\text { Concentration( } \boldsymbol{\mu g} / \\
\mathrm{ml})\end{array}$ & $\begin{array}{c}\text { Mean } \\
\text { Peak } \\
\text { Area }\end{array}$ & SD & \%RSD \\
\hline 1 & 15 & 133510 & 326.45 & 0.24 \\
\hline 2 & 20 & 178059 & 795.66 & 0.44 \\
\hline 3 & 25 & 225464 & 132.06 & 0.05 \\
\hline
\end{tabular}

\begin{tabular}{|c|c|c|c|c|}
\hline Sr.No. & Day & $\begin{array}{c}\text { Concentration } \\
(\mu \mathrm{g} / \mathrm{ml})\end{array}$ & SD & $\%$ RSD \\
\hline \multirow[t]{3}{*}{1} & Day1 & \multirow[t]{3}{*}{15} & \multirow[t]{3}{*}{142.68} & \multirow[t]{3}{*}{0.10} \\
\hline & Day2 & & & \\
\hline & Day3 & & & \\
\hline \multirow[t]{3}{*}{2} & Day1 & \multirow[t]{3}{*}{20} & \multirow[t]{3}{*}{171.34} & \multirow[t]{3}{*}{0.09} \\
\hline & Day2 & & & \\
\hline & Day3 & & & \\
\hline \multirow[t]{3}{*}{3} & Day1 & \multirow[t]{3}{*}{25} & \multirow[t]{3}{*}{665.37} & \multirow[t]{3}{*}{0.29} \\
\hline & Day2 & & & \\
\hline & Day3 & & & \\
\hline
\end{tabular}

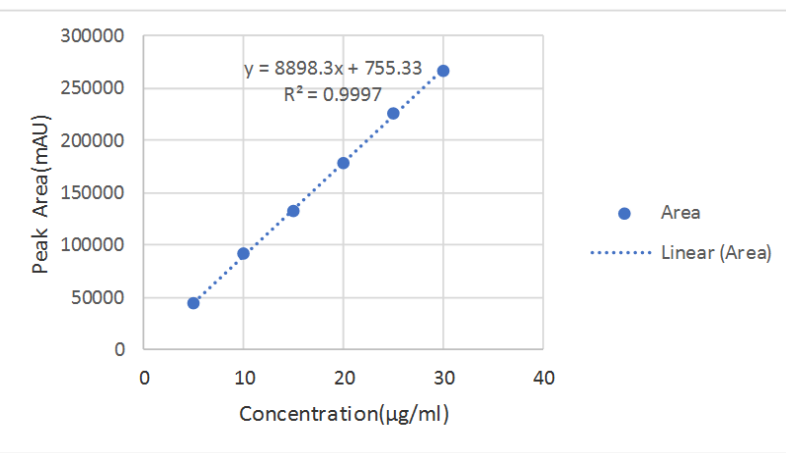

Figure 8: Calibration curve of Azilsartan. 


\begin{tabular}{|c|c|c|c|c|c|}
\hline \multicolumn{5}{|c|}{ Table 8: Accuracy and percent recovery validation of quantitative HPLC method of Azilsartan } \\
\hline Levels(\%) & $\begin{array}{c}\text { Amount of sample } \\
\text { added( } \boldsymbol{\mu g} / \mathbf{m l})\end{array}$ & $\begin{array}{c}\text { Amount of standard } \\
\text { added }(\boldsymbol{\mu g} / \mathbf{m l})\end{array}$ & $\begin{array}{c}\text { Amount recovered( } \boldsymbol{\mu g} / \\
\mathbf{m l})\end{array}$ & \%Recovery & $\%$ RSD \\
\hline 50 & 20 & 5 & 5.12 & 100.25 & 0.73 \\
\hline 100 & 20 & 10 & 10.16 & 98.94 & 0.71 \\
\hline 150 & 20 & 15 & 14.86 & 100.46 & 0.49 \\
\hline
\end{tabular}

\begin{tabular}{|c|c|c|c|}
\hline \multicolumn{4}{|c|}{ Table 9: Robustness study } \\
\hline \multicolumn{2}{|c|}{ Parameter } & $\begin{array}{c}\text { Retention } \\
\text { Time (Rt) }\end{array}$ & $\begin{array}{c}\text { \%RSD of } \\
\text { Peak Area }\end{array}$ \\
\hline \multirow{3}{*}{$\begin{array}{c}\text { Flow Rate } \\
\text { (ml/min) }\end{array}$} & 0.8 & 3.543 & 177685 \\
\cline { 2 - 4 } & 1 & 3.516 & 177795 \\
\cline { 2 - 4 } & 1.2 & 3.498 & 177432 \\
\cline { 2 - 4 } & Mean & 3.519 & 177637 \\
\cline { 2 - 4 } & SD & 0.022 & 186.13 \\
\cline { 2 - 4 } & $\% R S D$ & 0.62 & 0.104 \\
\hline \multirow{4}{*}{$p H$} & 4.5 & 3.509 & 178452 \\
\cline { 2 - 4 } & 5 & 3.516 & 177543 \\
\cline { 2 - 4 } & 5.5 & 3.535 & 177623 \\
\cline { 2 - 4 } & Mean & 3.52 & 177872.7 \\
\cline { 2 - 4 } & SD & 0.013 & 503.3 \\
\cline { 2 - 4 } & \%RSD & 0.28 & 0.29 \\
\hline
\end{tabular}

Table 10: Summary of optimized RP-HPLC-PDA method.

\begin{tabular}{|c|c|}
\hline Parameter & Results \\
\hline Regression coefficient & 0.9996 \\
\hline Range & $5-30 \mu \mathrm{g} / \mathrm{ml}$ \\
\hline Regression equation & $\mathrm{y}=8959.1 \mathrm{x}+46.5$ \\
\hline Repeatability & $0.59 \%(\mathrm{RSD})$ \\
\hline Inter-day precision & $0.09-0.29 \%(\mathrm{RSD})$ \\
\hline Intra-day precision & $0.05-0.44 \%(\mathrm{RSD})$ \\
\hline Robustness & Robust \\
\hline Specificity & Specific \\
\hline Assay & $99.66 \%$ \\
\hline
\end{tabular}

of the factor was anticipated and none of the factors go beyond the extreme and in this way proved the studied independent variables did not impact the results.

\section{LOD and LOQ}

The smallest amount can be detected and quantified by using the developed HPLC method. The detection limit was connected as a signal to noise ratio of $3: 1$ while quantification limit was specified as a signal to noise ratio $10: 1$. The $\%$ RSD was calculated.

\section{Assay of marketed tablets of Azilsartan}

The developed method was used for the estimation of azilsartan in oral tablet dosage form. The \% assay was found to be $99.66 \%$ of Azilsartan from the tablet dosage form. It defines there was no interference and a high \% recovery was found in the formulation excipients in the retention time of the drug shows the selectivity of the method for estimation of Azilsartan in the tablet dosage form.

In the preliminary experimental run Azilsartan was separated with trials using a mobile phase consisting of water and acetonitrile at $\mathrm{pH} 5$ adjusted by orthophosphoric acid in ratio $80: 20 \% \mathrm{v} / \mathrm{v}$ and flow rate $0.8 \mathrm{ml} / \mathrm{min}$. The drug was found to be retained, but the plate count was less and the tailing factor was more. Using the design of experiment approach the method was optimized using the mobile phase as water and acetonitrile in ratio $75: 25 \% \mathrm{v} / \mathrm{v}, \mathrm{pH}$ adjusted to 5 and flow rate $1 \mathrm{ml} / \mathrm{min}$. As a result, retention time was decreased with the improvement of theoretical plates and less tailing factor. By using the QbD approach the optimized mobile phase condition found that it was economical as well as got the responses with high accuracy and precision. The linearity was found within $5-30 \mu \mathrm{g} / \mathrm{ml}$ and in precision, \% RSD was found to be 0.59 which is less than 2. In this RP-HPLC method, the method was successfully validated in the optimized conditions and the validation parameters were within the limits. The results were shown in Table 10.

\section{CONCLUSION}

A reliable, precise, accurate, robust and cost-effective RP-HPLC method by the DoE approach using BoxBehnken design has been developed for the estimation of Azilsartan in bulk and pharmaceutical oral tablet dosage form. The systematic approach was utilized for method development which includes beginning with the determination of target profile characteristics, instrument qualification, risk assessment, design of experiment and validation. The design of experiment approach was successfully and effectively applied in the development of Azilsartan. The precision was found to be under acceptance criteria. There was no interference of excipients used in the formulation. According to ICH, USP and FDA guidelines, the method was validated. Hence, the outcome of this study will be very useful to researchers and industrial personnel. 


\section{ACKNOWLEDGEMENT}

I wish to thank various people for their contribution to this article Mrs. Suvarna Vanjari, Mrs. Vinita Patole, Dr. Rajendra Patil, Principal of J.S.P.M's Rajarshi Shahu College of Pharmacy and Research, Tathawade, Pune for their valuable support.

\section{CONFLICT OF INTEREST}

The Authors declare no conflict of interest.

\section{ABBREVIATIONS}

HPLC: High Performance Liquid chromatography; ICH: International Conference on Harmonization; CQA: Critical Quality Attributes; QbD: Quality by Design; ATP: Analytical Target Profile; SD: Standard Deviation; ANOVA: Analysis of Variance; PDA: Photo diode array.

\section{REFERENCES}

1. Baker WL, White WB. Azilsartan medoxomil: A new angiotensin II receptor antagonist for treatment of hypertension. Annals of Pharmacotherapy. 2011;45(12):1506-15.

2. Zaiken K, Cheng JW. Azilsartan medoxomil: A new angiotensin receptor blocker. Clinical therapeutics. 2011;33(11):1577-89.

3. Perry CM. Azilsartan medoxomil. Clinical drug investigation. 2012 Sep 1;32(9):621-39.

4. Ahmadian EA, Eftekhari AY. Khosroushahi, Current research of the reninangiotensin system effect on stem cell therapy, renin-angiotensin systempast, present and future. In Tech. 2017.

5. Rodrigues-Ferreira S, Nahmias C. G-protein coupled receptors of the reninangiotensin system: New targets against breast cancer?. Front Pharmacol. 2015;6.

6. Kurtz TW, Kajiya T. Differential pharmacology and benefit/risk of azilsartan compared to other sartans. Vascular Health and Risk Management. 2012;8:133.

7. Gorla R, Nagaraju CH, Sreenivasulu B, Sreenivas N, Korupolu RB. New simple UV Spectrophotometric Method for determination of Azilsartan Medoxomil in bulk and pharmaceutical dosage forms. Int J Res Pharm Biomed Sci. 2013;4:1133-7.

8. Kaushik D, Kaur J, Kaur VP, Saini B, Bansal Y, Bansal G. Forced degradation, LC-UV, MSn and LC-MS-TOF studies on azilsartan: Identification of a known and three new degradation impurities. Journal of Pharmaceutical and Biomedical Analysis. 2016;120:202-11.

9. Nalawade V, Joshi S. Development and validation of LC-MS/MS method for simultaneous determination of Azilsartan Medoxomil and Chlorthalidone from the human plasma. Journal of Pharmaceutical Sciences and Research. 2019;11(7):2533-7.

10. Hussein LA, Magdy NN, Ibrahim MA. Stability-indicating RP-UPLC method for simultaneous determination of azilsartan medoxomil and chlorthalidone in tablets in the presence of its degradation products. Journal of Chromatographic Science. 2019;57(3):213-9.

11. Dighe NS, Thorat SK, Shinde GS, Dhamak KV. Quantitative Estimation and Validation of Chlorthalidone and Azilsartan Medoxomil in Bulk and Tablet Dosage Form by using RP-HPLC. Journal of Drug Delivery and Therapeutics. 2019;9(4-s):264-8.

12. Soliman MM, Darwish MK, Abdel-Razeq SA. Determination of Amlodipine Besilate and Azilsartan Medoxomil by UHPLC, HPTLC and
Spectrophotometric Techniques. International Research Journal of Pure and Applied Chemistry. 2019;1-3.

13. Ebeid WM, Elkady EF, El-Zaher AA, El-Bagary RI, Patonay G. Stabilityindicating RP-LC method for determination of azilsartan medoxomil and chlorthalidone in pharmaceutical dosage forms: Application to degradation kinetics. Analytical and Bioanalytical Chemistry. 2014;406(26):6701-12.

14. International Conference on Harmonization of Technical Requirements for Registration of Pharmaceuticals for Human Use. $\mathrm{ICH}$ Harmonised Tripartite Guideline: Pharmaceutical Development Q8 (R2). 2009.

15. Lionberger RA, Lee SL, Lee L, Raw A, Lawrence XY. Quality by design: concepts for ANDAs. The AAPS journal. 2008 Jun 1;10(2):268-76.

16. International Conference on Harmonisation of Technical Requirements for Registration of Pharmaceuticals for Human Use. $\mathrm{ICH}$ harmonized tripartite guideline; Quality Risk Management Q9. 2005.

17. International Conference on Harmonisation of Technical Requirements for Registration of Pharmaceuticals for Human Use. ICH harmonized tripartite guideline; Pharmaceutical Quality System Q10. 2008.

18. Panda SS, Bera VV, Beg S, Sahu SK. Ultrafast liquid chromatographic method development and its validation for quantification of telaprevir in pharmaceutical dosage form by using quality by design approach. Journal of Chromatographic Science. 2015;53(7):1193-202.

19. Savic IM, Marinkovic VD, Tasic L, Krajnovic D, Savic IM. From experimental design to quality by design in pharmaceutical legislation. Accreditation and Quality Assurance. 2012;17(6):627-33.

20. Chaudhari SR, Shirkhedkar AA. Design of Experiment Avenue for development and validation of RP-HPLC-PDA method for determination of apremilast in bulk and in in-house tablet formulation. Journal of Analytical Science and Technology. 2019;10(1):10

21. Thakur D, Kaur A, Sharma S. Application of QbD based approach in method development of RP-HPLC for simultaneous estimation of antidiabetic drugs in pharmaceutical dosage form. Journal of Pharmaceutical Investigation. 2017;47(3):229-39.

22. Naazneen S, Sridevi A. Stability-indicating RP-HPLC method for the simultaneous estimation of azilsartan medoxomil and chlorthalidone in solid dosage forms. International Journal of Pharmacy and Pharmaceutical Sciences. 2014;6(6):236-43.

23. Nadpara NP, Thumar RV, Kalola VN, Patel PB. Quality by design (QBD): A complete review. Int J Pharm Sci Rev Res. 2012;17(2):20-8.

24. Mogal V, Dusane J, Borase P, Thakare P, Kshirsagar S. A review on quality by design. Pharm Biol Eval. 2016;3:313-9.

25. Karmarkar S, Garber R, Genchanok Y, George S, Yang X, Hammond R. Quality by design $(\mathrm{QbD})$ based development of a stability indicating HPLC method for drug and impurities. Journal of Chromatographic Science. 2011;49(6):439-46.

26. Gandhi SV, Vrushpriya HH. Development and validation of HPTLC stability indicating method for estimation of Azilsartan Medoxomil using fluorescence mode. International Journal of Pharmacy and Analytical Research. 2016;5(3):497-3.

27. Gandhi S, Mittal P, Pahade A, Rege S. Development and validation of stability indicating hptlc method for estimation of azilsartan medoximil. Inter J Pharm Sci. 2015;6(1):224.

28. Li W, Rasmussen HT. Strategy for developing and optimizing liquid chromatography methods in pharmaceutical development using computerassisted screening and Plackett-Burman experimental design. Journal of Chromatography A. 2003;1016(2):165-80.

29. Karpe S, Sonawane S, Rahade P, Kshirsagar S. Development and validation of a bioanalytical RP-HPLC method for Azilsartan medoximil with liquid-liquid extraction. Int J Pharm Pharm Sci. 2016;8(2):164-8.

30. Sravani P, Kumar SR, Duganath N, Devanna N. Method development and validation for the simultaneous estimation of azilsartan and chlorthalidone by RP-HPLC in pharmaceutical dosage form. Int J Pharm Sci. 2014;4(5):725-9.

31. Guideline IHT. Validation of analytical procedures: text and methodology Q2 (R1). International conference on harmonization, Geneva, Switzerland. 2005;11-2. 
PICTORIAL ABSTRACT

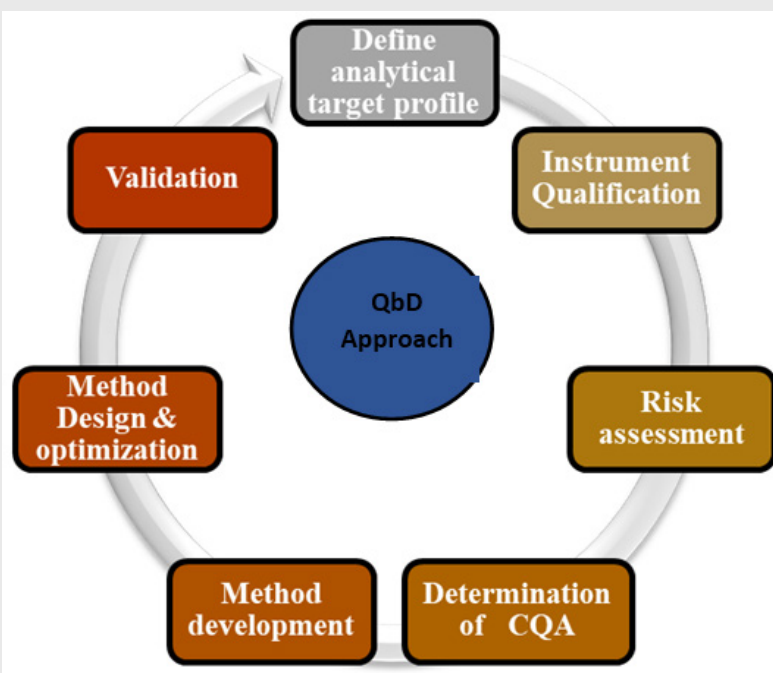

\section{SUMMARY}

A reliable, sensitive, accurate and robust method was developed and optimized using the $\mathrm{QbD}$ approach with a high degree of effectiveness of requirements for estimation of Azilsartan in the tablet dosage form. Implementation of the $\mathrm{ObD}$ approach for chromatographic method development and optimization involves multiple steps. It consists of the first step of the determination of the target profile which sets the acceptance criteria. The second step consists of a review of possible risks (using the Ishikawa diagram) to identify the critical method parameters. The fourth phase includes based on risk assessment critical quality attributes were determined. The fifth phase consists of developing method. The sixth phase includes method optimizing using suitable design of experiments (DoE). The validation was performed according to $\mathrm{ICH}$ guidelines.

\section{About Authors}

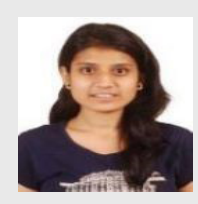

Ms. Siddhata Deshmukh has completed B.Pharm and pursuing M.Pharm in Quality Assurance department from JSPM's Rajarshi Shahu College of Pharmacy and Research, Tathawade, Pune.

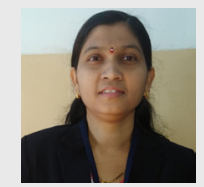

Mrs. Suvarna Vanjari has completed B. Pharm and M.Pharm. Presently, she is working as Assistant Professor of Pharmaceutical Chemistry Department in JSPM's Rajarshi Shahu College of Pharmacy and Research, Tathawade, Pune.

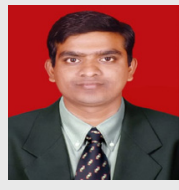

Dr. Rajendra Patil has completed Ph.D and currently working as HOD of Pharmaceutical Chemistry Department in JSPM's Rajarshi Shahu College of Pharmacy and Research, Tathawade, Pune.

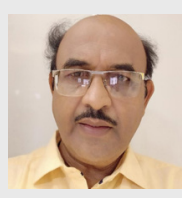

Dr. Kishanchandra Khandelwal is Principal of JSPM's Rajarshi Shahu College of Pharmacy and Research, Tathawade, Pune.

Cite this article: Deshmukh SA, Vanjari SS, Patil RB, Khandelwal KR. Application of Design of Experiment Based Innovative Approach in Method Development and Validation of RP-HPLC for Estimation of Azilsartan in Bulk and Pharmaceutical Tablet Dosage Form. Indian J of Pharmaceutical Education and Research. 2020;54(3s):s657-s666. 